\title{
The Différance Engine: Videogames as Deconstructive Spacetime
}

\author{
Tony Richards
}

\begin{abstract}
The purpose here is to intervene within some dominant strands of videogame scholarship and propose a more problematic relation to our object. The two dominant tendencies taken-up here represent what has come to be self-styled as a media studies 2.0 model, over and against a supposedly previously dominant (and retroactivated as outmoded) 1.0. ${ }^{1}$ Proposed in opposition to these somewhat sweeping positions will be a deconstructive model which, while disagreeing with these theoretical 'algorithms', would not believe itself to be leading a charge toward any notionally more thoroughgoingly circumnavigating 3.0 account. Specifically, while the 2.0 account proposes a "new" active first-person Performative framework versus an "old" third-person indicative Constative, we would recommend a reworked iterative-Performative as propounded in the works of Derrida and Butler.
\end{abstract}

Keywords: différance, undecidable, narrative, first-person, third-person, performative, constative, interpellation, suture, reflexivity.

$$
* * * * *
$$

\section{Introduction}

To briefly recount the saga: the outmoded 1.0 account $^{2}$ tended to grant supremacy to the machine, supply, or server side of the communicative equation leaving for the audience only an intractable, non interactable blank space to be crowded-out by an insuperable-power: the subject(-objective) is overwhelmed by the text's all too powerful mode-of-address. Within this previously dominant model of domination then each 'text' would form (from its secured vantage point) a linear-perspectival control-engine that would either hypodermically inject (older-outmoded theory) or interpellate (more modern-outmoded theory) their object-individual as their subject. This denial of any space either to play or to poke polysemical holes into the socialising fabric of the oncoming text constituted the figure then of an indivisible program(me) acting as some locally firewalled representative of a much larger media-industrial eco-system. While some theorists felt that this did a disservice to the multifarious positionality of the 
The Différance Engine: Videogames as Deconstructive Spacetime

receiving audiences (that there was always a residual meaning allowance or a polysemic-playspace ${ }^{3}$ within the static and weaved net of a particular text's 'material' signifiers), there was still nonetheless a strong server-sided control of what composed the message (to borrow de Certeau's language: there is still an organised supermarket from which we must shop, even if we get to play a little within its space ${ }^{4}$ ).

Let us timeshift. The tectonic plates of the media were noticeably shifting around the early 1990's. A crossing of the divisive stage-boundary began (hypercards for example ${ }^{5}$ ) with the birth of 'the wreader', a sort of Barthesian writerly but this time adding signifier, paradigm and pathway choices (what Aarseth would later call 'variable expression' ${ }^{, 6}$ ) to the aforementioned semantic latitude of those signifieds. The recent birth of these interactors began to make such ageing theories, even of semantic/subcultural play $^{7}$, seem untenable. The tectonics of the object itself began to drift from under these theorists' weary feet.

This move then from texts with relatively determining meta-narrators ${ }^{8}$ to texts that stepped outside of such trajectorial-boundaries demanded a somewhat different outlook if a media theorist's reflections were to keep pace with media practsumption (consumption-practice) and to offer something fit for a changing media infrastructure. As example of this reality-pull, in the UK a lively email debate amongst scholars ${ }^{9}$ ensued within which a number of new-broom media educators pointed out the changing shape of their student's more ludic ${ }^{10}$ media experiences (algorithmically: how can we carry on teaching film and media theory 1.0 when students have moved on to the internet, mobile phones and games and whose media experiences are thus far from continuous and playless?). In place of the ideologically determined subject exemplified by Althusser et al, these scholars suggested Media Studies 2.0 where a reflexive subject, prepared for variously by Caillois, Butler and Giddens, might provide a more fitting analytic. Before however looking at 2.0's more proper and up-to-date approach let us look in a little more detail at this 1.0 model's attempted expansion into new media territory.

\section{Theory 1.0: Third-Personed Spectatorial-Constatives}

As an exemplar for the problematic extension of so-called media theory 1.0 into the alien realm of games let us present a brief case study. Rehak ${ }^{11}$ reissues (into games) interpellation or the 'hey you!' function of the text, from its original setting within film theory ${ }^{12}$ and puts it to work in its new surroundings by finding equivalents or replacements within the videogame. This occurs in much the same way as when for film theory MacCabe ${ }^{13}$ famously replaced literature's 
omniscient written third-person commentary (operating everywhere that is outside character quotations) with the film camera and edit's positioning of what he termed dominant specularity. Rehak's replacement (or supplementation) of the film camera function in the game actually makes the immersion or 'loss' to the space more powerful than ever:

[F]irst, the use of subjective POV to create a newly participatory role for the spectator; and second, the concept of interpellation and its function, within discourse, in constructing apparently unified subject positions [...] the subject position created through shot-reverse-shot is replaced in the FPS [firstperson shooter] by a camera simulated through software rendering of these three-dimensional spaces [...] literalises the conceit of an embedded diegetic participant [my emphasis] that cinema, because of its material technologies, can only imply. ${ }^{14}$

While in many ways an impressively argued paper, the above excerpt betokens an overly optimistic reorienting of apparatus theory imported inappropriately into the game's quite undecidable 'spacetime'. For here to speak of a "diegetic participant" is to take the concept of 'diegesis' (storyworld) and to concomitantly equate the player as an insider-character (or here paradoxically flipped outsider-captured) embedded within a 'space' which is in fact neither quite text nor non-text (non-text would be something anarchically without overarching arché-textual structure like the internet): being neither decidedly diegetic nor extra-diegetic ${ }^{15}$. This undecidable difficulty will later form an important component within our own investigation of the gamic spacetime.

Further, according to Rehak the suturing function of the cinematic shotreverse-shot (presumed to subject the spectator within the difference of framing positions ${ }^{16}$ ) finds a direct equivalence in the game's free-roaming simulated camera that would here make the player forget their difference and distance from the presumed diegesis. A sort of umbilical-alliance here comports the gamecontrol as of a prosthetic extension (for that control would extend the screen outward) and in so prosthetising-the-player would swallow the player into the 'diegetic' matrix and make of them a mere third-person-subject of the space ${ }^{17}$.

As third-person subject of the space the gamer would seem to misrecognise their pre-textual identity for that of a character already embedded within the game's "diegesis". To unpack this problematic idea of a diegetic 
The Différance Engine: Videogames as Deconstructive Spacetime

already-embeddedness it will be worth looking in a little more detail at this borrowed model of the cinematic subjection and misrecognition before returning to Rehak's own gamic application. According to Doane ${ }^{18}$ identification within the cinematic apparatus works on three distinct levels. After Metz ${ }^{19}$ she points out that these three modes of identification are with the character, of objects (and issues) and finally with the projection/screen as an act of 'the gaze' or looking in itself. This latter identification acts as a mode of primary identification which subsumes and forms the condition of the possibility of the other two (which are contentual and thus downstream or secondary in form).

By the mere act of looking the cinematic spectator forgets their own distinction and is thus enveloped by and made subject of the apparatus. Doane points out that " $[\mathrm{T}]$ he pleasure of misrecognition ultimately lies in the confirmation of the subject's mastery over the signifier"20. This "mastery" is however the very misrecognition that is their actual non-mastery (for this gaze or look does not master, bring-forth or change the signifier). This act of looking within an apparatus which envelopes causes the spectator to misrecognise their look for a look which has the power to bring-forth. On this model, this misrecognised power to bring-forth, to master or 'write' the space in-front in fact writes or inscribes the passive spectator themselves: the mistaken feeling of performing (of being the hero) within the film constitutes the spectator's very passivity or actual non-mastery. For the primary-projection of the screen itself and the secondary-look of the protagonist within that screen hollows-out both the spectator's subjection as well as the film's own fixed narratological futurity. This voyeuristic misrecognition of having potency over the cinematic signifier would seem then to write, inscribe or suture them securely into the screen-space; writing them ' $i n$ ' as though they were the themselves third-person constative character already hardwired and pre-written within the film's screenplay or cinematic ecriture. Such a self-less cinematic subjection leaves no room for any play or indeterminacy over the signifier. How can this be for the videogame?

By expanding this model into the game any screen/play is thus turned into a more powerfully functioning and diegetically immersed linearising screenedplay. To return again to Rehack. Another strategic re-encounter with cinematic suture makes the point of a cinematic sort of subjection all the more strongly:

The film spectator's role as an implied observer of narrative events -an "absent one" flickering ghostlike through the diegesis, positioned anew from shot to shot- is concretised in 
the video game imaginary through the figure of the avatar, a "present one" standing in for the player, who chooses the path of the camera-body with apparent freedom. The disavowal necessary to gameplay is like the "Yes, that's what I see" of successful cinematic suture, but goes further: it is "Yes, that's what I $d o, 21$

This "Yes" is of course an inauthentic and very small 'yes' which would remediate the succumbing-slumber of a massed cinematic 'they-self ${ }^{22}$, which then [b]ecomes an extreme form of subject positioning, a scenario of continuous suture $^{, 23}$. Without the 'breaks' that film's shot-reverse-shot lends to the viewer, the "continuous suture" of the game actually makes for a more powerfully immersive apparatus or mechanism; one, as it were, without breaks ${ }^{24}$. This all begins to sound so much like slavery. For the game program's the gamer, just as the programmer would first have presumably programmed 'the program, ${ }^{25}$..

While on the 1.0 side we have the remediated ${ }^{26}$ locked conveyer-belt of the filmic world so theorised, on the other (new side) we have a theory which would supplant such subjections. For these media 'performances' really cannot be seen as 'programs' and call for a much freer interactor to marry-up with the much freer post-programming of this modern world. Enter 2.0.

\section{Theory 2.0: First-Person Performatives}

Here we can see coming into view a first-person experience in the sense of someone who comes 'before' something in all their phenomenological purity. Keeping this in mind it is important to explore here two key components in 2.0's armoury: 'reflexivity' and 'performativity'. To take the first. Key Media 2.0 theorist Gauntlett argues that sociologist Giddens' notion of reflexive identity provides a key lever in coming to a clearer theoretical understanding of the contours of the present media landscape:

Giddens is fascinated by the growing amounts of reflexivity in all aspects of society, from formal government at one end of the scale to intimate sexual relationships at the other [...]. Doing things just because people did them in the past is - is the opposite of modern reflexivity. ${ }^{27}$ 
Thus we seem to have moved on from a traditional society with its unreflective doing-as-is-done; a machinic society of robotically pre-conscious 'they-selfs' where audiences were locked into the linearity of the media's handiwork. For here at least 2.0 agrees with 1.0, but argues however that now the world has moved along from such multitudinal 'they-selfs' to more singularly present 'my-self' narrations and more singular life-times. To outline the contours of these flexible identities Gauntlett utilises Judith Butler's notion of the 'Performative' but must first provide a little more flexibility for it in order to purchase a little more freedom for his own performative:

Furthermore we do not need to worry too much about this [that the perfomative is not radically free of the materiality of the body]: every thinker puts forward tools which we can choose to use, or modify, or reject. I feel that the tools in 'Gender Trouble' are more useful, relevant and exciting than some of the more cautious ideas in Butler's later works ${ }^{28}$

This above statement of 'intent' in itself performs a radical misunderstanding of a quotation it so recently (on the same page) utilised. Gauntlett finds some of Butler's later positions too "depressing" and "cautious"' and would prefer to take ideas from an earlier more vital time in her writings. But is not Butler pointing out within the quotation that in the previous book she had already said what she was so "depressingly" saying in the later one? She does this because she says that she is (having to) anchor and restate her position for those who skipped too lightly over what she had originally stated: thus in a strong sense she is here arguing for this later book contribution to be placed, as an interpretative buttress, within the space of those earlier passages to fend off such misinterpretations. Like the one Gauntlett is here making. For she says:

One of the interpretations that has been made of Gender Trouble is that there is no sex, there is only gender, and gender is performative. People then go on to think that if gender is performative it must be radically free. And it has seemed to many that the materiality of body is vacated or ignored or neglected here - disavowed, even [...] I think that I overrode the category of sex too quickly in Gender Trouble. I try to reconsider it in Bodies that Matter, and to emphasise the place of constraint in the very production of sex. ${ }^{29}$ 
Thus a double (portfolio) choice is being made here by Gauntlett as to what one takes from an informing theorist but without uniformly sticking to their word: one on the surface, the other buried out in the open. Whilst our point here may seem just a little too 'pedantic' there seems to be operating within Gauntlett a radical free-wheeling form of 'choice' radically independent of the materials being foraged upon. Taken within this rather flexible context there can never be any such thing as a (wilful) misreading and one can never then be accused of being selective or deceptive in cutting-up and wearing the parchments of one's sources: a very anarchic database or portfolio ${ }^{30}$.

These notions of 'reflexivity' and the individualised 'performative' along with related notions of what have been termed 'portfolio identities', aim towards a free-floating subjectivity cut free from the shackles of the traditional pre-reflexive, 'tied' or localised identities. A reflexive performativity such as this however appears to be a rather crude notion, tautologically pointing toward the figure of somebody standing on the ground of their own two feet. There is here within this 'reflexive-performativity' a sort of giddy auto-erotic freedom (a much simplified Nietzschean self-making) which would see itself as existing a levelabove and beyond the old traditional or grounded identities. Sherry Turkle along the similar lines talks of new media as spaces which allow us to explore and expand our individual identities ${ }^{32}$. On this model networking sites (also 'SecondLife' and videogames) would allow us to create ourselves again and show ourselves as new faces each time anew to the world (a morphous or protean being-outside-the-world).

An interestingly befuddled argument on the morphous and playful performativeness by Filiciak ${ }^{33}$ would merit further symptomatic investigation for the problem of identity which would seem to be both free (in that like Gauntlett he celebrates the protean nature of "postmodern" identity opportunities within games) yet sees the player as soon to be swallowed up into some cyberspatial self-forgetting (which presumably would land us back into a form of slavery?). He argues thus:

We are creating our "self" not as a linear process of construction and striving towards some original target -each identity we create is a temporary formation. Erosion of our individual "self" in macro scale is reflected in the fall of collected identities, like a nation [...] we cannot talk anymore 
about a single identity that produces temporary identities subordinate to itself. Thus in the era of electronic media we should rather talk about hyperidentity, which is related to identity as hypertext to a text. ${ }^{34}$

However four pages earlier we find that such playful opportunities for morphing our identities is based yet again on a model where the player finds themselves con-fused with the textual universe within which they find themselves wrapped up. The power of Cinematic identification again finds itself rehoused:

The process of secondary identification taking place in cinema theatres depends paradoxically on distance while in the case of games we encounter something more than just intimacy. Identification is replaced by introjections-the subject is projected inward into an "other". The subject (player) and the "other" (the onscreen avatar) do not stand at the opposite sides of the mirror anymore-they become one. ${ }^{35}$

How to square this rather contradictory argument? Here, as somewhat obliquely alluded to above, we find a common ground between 1.0 constative subjection theory and 2.0 reflexive performative theory. Both are equally symptomatic of an ideology of 'the arrival'. In both wrapping up a constative completion of a subjection to the apparatus (1.0) or conversely a completion of reflexive-performative absolute self-presence (2.0) both positions end up equally saying the same thing: "the space and the user are indivisible". For as a program-space we cannot be divided apart from it and as a me-space we equally cannot be divided apart from it (for it gives me everything $I$ would want whatever this $I$ turns out to be when floating around itself). To begin to close-up the 2.0 performative stage of our argument: by being able to choose our avatar and then change their position we would seem to float-free upon cyberspatial air, destabilising any previously dominant Cartesian or Euclidean coordination.

So here on the internet and within cyberspace we are within the presence of very concrete and open wormholes and thus the true death of the boundary would seem to be imminently or immanently upon us. The private, carved-off space of the previously dominant 'cogito-text' now gives way to a sort of infinite bleeding-out, as all the connections which previously were furtively sought out (by merely reading) become open and available as destinations (of reflexive selfbecoming). Within six hyperlinks then we experience a giddy separation from 
our original "location". The olde texts of 1.0 then give-way to a mere resource and thus throw us back upon our own giddy and now free-roaming self-present identities. This self-present first-person performative self-movement will need much deconstructive unpacking.

\section{First-Person Multiple: Iterable Performatives}

Could a performative utterance succeed if its formulation did not repeat a "coded" or iterable utterance, or in other words, if the formula I pronounce in order to open a meeting, launch a ship or a marriage were not identifiable as conforming with an iterable model, if it were not then identifiable in some way as a "citation"?...In such a typology, the character of intention will not disappear; it will have its place, but from that place it will no longer be able to govern the entire scene or system of the utterance. ${ }^{36}$

The Performative, here reinterpreted by Derrida (and also quoted by Butler $^{37}$ to underline her own Derridean use of the performative) as quasicitation, always-already penetrates into the Constative (which we, and by extension 2.0 labelled as 1.0). Austin's performative ${ }^{38}$ would be the selfpresenting first-person singular-pronominal active present-participle of the "I-do" (furnishing the, for example, the famous speech act of the $I$-do of the wedding rites $^{39}$ ). This singular presence however is predicated and reliant upon (iterative) the 'past-perfect' of the "you-did" that would seem in comparison to this firstperson singularity to be an externally cold and stale recording, citation or writing technology ${ }^{40}$. Thus the citational writing-within-speech (we could recoin it archécitation) that is Derrida's own reworked 'performative ${ }^{41}$ points to a differrantialundecideability (between -but not beyond- 'performative' and 'constative' as opposites) that can also be seen to be at the heart of the videogame which neither a constative 1.0 theory nor the performative 2.0 theory could circumscribe. For in the game, as we will see, there is an excess or dissemination that overruns or invaginates the boundary of any third or first-person position.

Beyond these (1.0 vs. 2.0 ) views then, it is preferable that the game should not be conceived of as a program(me) at all. For within this compounded neologism both a closed 'program' (1.0) and a closed '(me)' (2.0) presumes a 
violatory concept of an outer hacking or breaching of erected 'meta' fences that would attempt to fend off such incursions or breechings by some notionally errant alterity. For in the old 'sovereign-spaces' of the linear media text or program(me) there are the countless protections against fore-seen audience dissention, dialogically contained within, as constitutive of their very boundary or notionally 'cleaved' singular-existence ${ }^{42}$ ). As a concomitant of this non-limit in the game, and at this point still in a measure of agreement with 2.0 , we must also be wary of utilising unproblematised concepts from film or literary-linear studies such as 'diegetic space'. For here a distinct or internal 'diegetic space' (to be divided off from the notionally 'extra-diegetic space' of the 'audient' encountering that "theatrical" en-closure) would create a too neat divide, frame or parergon which does no justice to the openly invaginated nature of the space that is the gamestaging $^{43}$ : the outlying districts of the game are not so circumavigable. This lack of a diegetic framing or of a carved-off narrative space becomes all the more conspicuous when we see that there is no 'One' in the sense of a clear narrative agency. Here we come upon the importance of the first/third person problem for the videoogame.

In the game there is a clear (and essential) undecidability between the first and the third person subject positions (performative and constative respectively) whose vibrating-interlace will deny the ability of the space-of-play to wrap up its incorporated 'protagonist'. Before coming to land squarely on this however we must briefly look at a very important transition between the game and its linear subject-position forebears, one also that makes it very different to the externality of subject positions within the internet experience (could one here even think in the region of first or third person?). Within literature, and in its transportation to film, the difference of the first and the third-person never hands over an active 'signifier' arranging role to the person who is doing the reading or the spectating (hence now the neat new celebratory baptismal-neologism of the morphed reader+writer $=$ wreader $)$. The handing over of the optical first-person position in a few select linear-films never hands over the reigns to the viewer however. This is a very different to first and third undecidables within the game $^{44}$. One need only look at one of film's famous (and few) incursions into the "first-person" territory to see the difficulties of taking up the optic alignment and concomitantly then assuming to make of the spectator the key player.

Montgomery's Film-Noir 'Lady in the Lake ${ }^{, 45}$ was an experiment in film which took cinematic suture and the dominant point-of-view and transformed these into a constant optical-point-of-view. Here then we rarely saw the star of the show (Montgomery himself) for all the 'other' eyes in the film looked directly 
into 'our' protagonistic ones. This experiment was famously a failure for the voyeuristic distance so beloved of cinema (Mulvey ${ }^{46}$ et al) would paradoxically prevent the 'immersion' of stepping into the shoes of the screen-party rather than witnessing the scene from an associational distance. Another problem is the control of a space of comparison where we would be needed to be ever-present and thus outside of the constant locked character-optic. For if every component within the narrative-space is restricted to our optical-presence then unrestricted aspects unperceived by us 'the character' could not be compared or controlled by the omniscient narration (the obvious point about suspense as Hitchcock pointed out to Truffaut ${ }^{47}$ is showing more than the character knows and thus increasing our sense of empathy at their plight; for example a bomb ticking away under their seat). Thirdly, and most obviously for our purposes, the optical aspect does not hand over the reins, for nothing in the space is ever re-arranged by any extradiegetic empirical viewing. On these three grounds at least ${ }^{48}$ then the game is prevented from coinciding with such narrational first or third personage; for the interactivity of the game makes a mockery of the taking-up of these inside/outside positions: the game invaginates this divide.

Games then in being a haunted ${ }^{49}$ différance-engine operate on the very boundary distinction of first and third person, text/and non-text, of performative and constative and of presence and absence. Designers are still mistakenly fighting (pragmatologically) to create a first-person performative with the additional security of the cinematic third-person constative: hence the promised 'Cinematic' experience which game's covers and cutscenes often wish to foreground ${ }^{50}$ ). This battle however is headed in entirely the wrong direction and cannot complete its mission, as the game is situated from bottom on openings. Let us look at a game which more openly welcomes or embraces its gamic nature.

Like many games 'Black and White' helps to situate the player in relation to the gamespace they are about to embark on. Here they are given their 'character' and welcomed into the world of the game's 'parameters'. Once this universal-constative cutscene is over and the particular-performative game-element embarked upon, the player finds they are actually occupying at least two positions, to a large extent fracturing any perspectivisation in that traditionally unified sense. Firstly there is the Godmimicking 'above' position (literally 'a hand') where all areas of the game can be mobilised and manipulated, as in any decent top-down civilisation game. This leaves however a certain sense of de-focalised third-personage, placed as we are within the "third-person" position of distance or identificatory absence: 'outside' 
the occupied space of the ground level. Godlike. A second position is offered in answer to this hovering absent-outside whereby a second 'stand-in' character, now within the space, can be influenced, coaxed as of a proxy (a 'Beast' character chosen from a line-up of cow, lion or monkey; each with their own initial attributes). Here is where this game gets its impetus or identity, in this fractured sewing-between third and first. We are a God who chooses to intervene but we also intervene on a character which also intervenes on further characters (the population of a village it will interact with). A double-intervening. A double placement and interest: expanding as the game unfolds.

One interaction is constant, ready-to-hand and ours; obeying our controls, one-to-one, as in some I-extension. This extended- $I$ is omnipotent, immanent and always seemingly ours. The second stand-in however is relatively autonomous and capable of change, without any exacting guarantee. Through a sort of Pavlovian conditioning, the as yet ill-formed Beast's activities in this island-world are circumscribed, to an extent, given its relative autonomy, by reward and punishment (a stroke or a punch for example as it eats up villager or saves one from drowning). Thus the God-hand (for that is the tool with which we reward, punish and coax) upon the beast forms a sort of clumsy steering wheel that in attempting to drive the beast becomes a sort of conscious extension of it, in a Heideggerian sense. Our boundary with the beast is thus more fluid and removed than our ready-to-hand (of God) character which would seem also to be the first-person avatar of ourselves in-play (replacing the gun of the first-person shooter with the hand of our God-self). The beast-character acted upon by our extending-I hand then forms a secondary tool more present-to-hand, a tooltowards-a-narrative-branching that we are constantly and consistently aware of. This character itself is however never consistent or determined. A problem already. For these two differrant loci of operation (the hand and the beast; operator and operand) within themselves and within their difference provide also a variable and bleeding boundary dynamic between positions of first and the third person (God: for we are the position of the narratological third as in a linear text, experienced also as first in this game-text) and third-person-ed (beast) with attributes of a first which then provides the game's irresolvable identity-play (and thus showing the game to be beyond constative and performative as distinctives). Three narratological dynamical parties then are at play in their presence in this game. The complex, even psychotic, status of first and third person is rarely addressed or problematised within the critical literature and tends to be reduced to easy positional differentiations (as we have seen) of first or third 
and a clear diegetic arena within which their activities are thus then circumscribed.

Let us concentrate briefly a little more here then, for economic simplicity, on one of the boundary-between parties only: the beast. This beast, this other-self, has fluidly open-closed (invaginated) boundaries which prevent us from landing it as some diegetically encircled third person constative position. Also however as acted-upon it cannot be wrapped in any performative firstperson immediacy.

The opening few transactions of the game are centred on demonstrating to us its openness, its choices. Two character-guides or preliminary-chaperones, one angelic and one demonic (momentary helpers or traditional omniscient narrators as far as the game allows for such stabilised guiding hands) unravel the function of many of the game's core components. They foreground for example the concept of the building up of the behaviours of the beast that we have taken on. In this rather camp parody ${ }^{52}$ of the cartoon's (Good vs. Evil) disembodied 'inner voices' we are told how we can affect various outcomes. Here then after this restrictive nursery-slope (once we are on our own) the game becomes far from black and white. This is why a textual analysis cannot really take us any further down these multiply-forking paths. How can one textually analyse such a shaded uncertain and undecidable object? How then can one talk of a diegetically locked temporo-spatiality, where by definition either a first or third person position could be defined?

The beast, as neither constative third-person character nor performative first-person occupied tool, never sleepwalks along a path of calendar predestination. By coaxing the character, and by having it continually on the edge of a slipping-away-from-grasp, we find a haunting sense of its future attributes in its de-centred present movements within the story-world 'we-it' occupies; making of 'it-we' a flickering undecidable performative-constative (or as we saw earlier a Derridean re-coined performative). The beast is then is a de-central character of a morphous identity within this différance engine that is the slippery diegesis of the game's fluid futurity. The important fluidity of this future and the haunting of the other-path cannot help but make us aware of the question of other always-already hanging over present-absences.

That the 'present-diegesis' (the spacetime that the beast is "presently" inhabiting) is haunted by an-other diegesis makes any narrational absolute positioning of third-person constative eminently undecidable. That we are not free to operatively or performatively roam makes any metaphorical first-person 
'experiential' equally undecidable. Such undecidabilities that we are opening up here cannot be closed down by the wishful thinking of the protective absolute oppositions of third or first person. Thus we must put in place a more knowing, open and avowedly undecidable recoined performative which contains and admits of its constative-iterative.

This more knowing and thus less certain re-coined iterativeperformative must recognise that neither a 1.0 locked constative (third-person) beloved of apparatus theory, nor an open and free-roaming performative (firstperson) beloved of reflexive models is correct for these new media spaces such as the game. Identity here is never knitted nor unknitted but also never simply a happy combination or resolution of the two (hence no 3.0 synthetically appreciating or sublating these differences). This irresolvable un-becoming flickering of the first and the third persons provides a telling problem in this differrance-engine that is the videogame. That we cannot resolve this différance in the spacetime of the game may be something to celebrate...

...For the game itself does not end in either definition by the game or by walking away free within it. The game goes far beyond the game and we will not be walking away from it. For we are not really playing it.

We are facing our incompletion...

\section{Notes}

1 This of course purposefully and rather self-confidently utilises a computer program nomenclature to display a theoretical fitedness to the momentum of this modern world.

${ }^{2}$ Again we must underline the somewhat ironic sense of this progressive 1.0 versus 2.0 mounting of hostilities. A younger generation of media theorists (typified in the parties of Merin, Gauntlet et al) parcel-up as "1.0" a seeming homogenous unity which does not recognise ludic play. More particularly they seem to say that media studies 1.0 does not seem to recognise that the world has moved on into the more client-sided pursuits of games, the internet and social networking sites. Thus the technologies-of-the-teaching need an overhaul as they are in grave danger of being left behind and outstripped by their pedagogic student/objects (now turned teacher). Of course media theory was not previously sewn-up (or even sutured) by non-playful explanations. For example, one need only think of Fiske's classical re-deployment of de Certeau and Bakhtin (almost a repeat of Merin's re-deployment of Caillois) to see the role that play as tactics have had in the face of a seemingly faceless and strategic ideological power. It is 
of course this latter 'strategic' aspect (as representative of 'the server' serving media to a linear down-stream consumer) that has here come into question. Still does this create a neat 2.0 departure?

${ }^{3}$ See Fiske, J., Television Culture. Routledge, London, 1987 for a clear example of this position of carnivaleque consumption which refuses to unwrap its parcel in the symmetrical way that the giving institution would prefer.

4 See de Certeau, M., The Practice of Everyday Life, University of California Press, Berkeley and Los Angeles, 1988 for a classic examination of the organising strategies of institutions versus the resistant counter-tactics of their users, consumers, etc.

5 In 1987 with its System 6 operating system Macintosh Hypercards were much hyped and lead famously to popular games such as Myst as well as the popularising of interactive multimedia along with the Commodore Amiga's 'Amigavision' authoring system.

6 See Aarseth, A,. Cybertext: Perspectives on Ergodic Literature. The Johns Hopkins University Press, Baltimore and London, 1997. Though Aarseth rightly points out the difficult notion of a reader writing through choosing pathways, he points out that such choice does not in any way compete with a notion of writing.

Here we could name Jay .G. Blumer, Wolfgang Iser, John Fiske, Stuart Hall, David Morley, Ien Ang, Standley Fish, Henry Jenkins, Martin Barker and others

8 See MacCabe's 'Realism: Notes on Some Brechtian Theses' for a clear explanation of the workings of meta-narration within classic narrative texts.

${ }^{9}$ http://www.jiscmail.ac.uk/cgi-

bin/webadmin? $A 2=$ ind $0801 \& L=M E C C S A \& P=R 386 \& I=-3$ for a brief entry on Merrin's thinking on keeping up with strudent's ludic experiences also the intereseted reader could search the archive for "media studies 2.0" for other entries in this debate. This debate also responded to an outline by Gauntlet of his thinking on media theory 2.0 to be found here:

http://www.theory.org.uk/mediastudies $2 . h t m$.

${ }^{10}$ See Caillois R., Man, Play and Games, University of Illinois Press, Urbana and Chicago, 2001, for an influential analysis of the social functions of play from a number of angles including the ludic angle influential with Media 2.0 scholars.

11 Rehak, B. 'Playing at Being' in The Video Game Theory Reader ed. M.J.P. Wolf \& B. Perrron (Routledge, 2003) New York and London. p103-127. 
${ }^{12}$ Of course the use of the phrase 'hey you!' comes from Althusser in relation to the multitude of ideological state apparatuses but here interpellation makes us think of the use of subject positioning by writers of the cinematic apparatus such as Baudry, Comoli, Mulvey and Heath as well as others centering around the journals Screen and Cinetracts in the 1970's and 80s. For the interested reader, the every edition of Cinetracts is available in pdf format at the following website: http://dl.lib.brown.edu/cinetracts/

${ }^{13}$ MacCabe, C., 'Realism and the Cinema: Notes on Some Brechtian Theses' in Popular Television and Film, Tony Bennett (ed), BFI Press, London, 1981.

${ }^{14}$ Rehak op cit p.119.

${ }^{15}$ Indeed we could open up a whole can of worms here in the use of diegesis in any sense or conjoining of terms, difficult as it would be to throw it away; thus reducing the open-closed of the game to the openness and thus entire lack of diegesis of the internet, for example. We use 'extra-diegetic' here heuristically to denote the distance of the game from the diegesis of the film (and in the absence of a better concept) but extra-diegetic has been utilized rightly to refer to things like titles or peacocks in Eisenstein's 'October' which exist outside their respective story-spaces. This can may be worth opening however to expose the insurmountable narrative problems of the game. We can only mount an insubstantial challenge here ourselves.

${ }^{16}$ See Dayan D., 'The Tutor Code of Classical Cinema' in Movies and Methods, Bill Nichols (ed), University of California Press, Berkeley and Los Angeles, 1976, pp.438-450, as well as the chapter 'On Suture' in Heath, S., Questions of Cinema, Palgrave Macmillan, London, 1981, pp76-112.

${ }^{17}$ For the suturing of the spectator "completed" within the film's shot-reverseshot takes the third-person 'juxtapositions' of the film's dominant specularity and enacts for the audience a misrecognition of first-person identity. For more on misrecognition see Rosen, P., Narrative, Apparatus, Ideology, Columbia University Press, New York, 1986. Also see the two entries immediately below.

${ }^{18}$ Doane M.A., 'Misrecognition and Identity'in Explorations in Film Theory: Selected Essays from Cinetracts, Ron Burnett (ed), Indiana University Press, Bloomington and Indianapolis, 1991, p15-25.

${ }^{19}$ See Metz, C., The Imaginary Signifier: Psychoanalysis and the Cinema, Indiana University Press, Bloomington and Indianapolis, 1986.

${ }^{20}$ Doane op. cit. p. 19

${ }^{21}$ Rehak, op. cit. p121. 
${ }^{22}$ Heidegger's phrase (translated from 'das-man') for an inauthentic 'Being' which follows the machinic flock showing for example an inauthentic beingtowards-death (a disavowal of its real-coming) and thus a lack of authenticity in one's present comportments.

${ }^{23}$ Rehak, op. cit. p122.

${ }^{24}$ Here we see a paradox of 'the break' which there is no real time to go into here but which would take the 'break' of the shot-reverse-shot (something screen theory takes to actually suture) and by taking them away would suture ever the more. Here lies an illogical paradox in Rehak's argument that would be worth unpicking further (beyond its confines in Rehak's usage to further issues within notions of remediations of the cinematic).

${ }^{25}$ Here again there is the paradox of 'programming' which some remediating Screen theorists take as an enslaving power of the game: programming as if to program audient outcomes. We will be looking into this a little further in.

${ }^{26}$ Bolter a little like Rehak sees video games as carrying on or 'remediating' the work achieved by earlier media.

${ }^{27}$ Gauntlett, D. Media, Gender and Identity: An Introduction, Routledge, 2002 p97.

${ }^{28}$ Ibid p. 142

29 Osborne, P. \& Segal, L., 'Gender as Performance: An Interview with Judith Butler', Radical Philosophy 67 (Summer 1994), pp32-39.

30 Here performative is closed down from any prior materiality to a radical freechoice without standing-order. This combination of self-presence and reflexivity provides a tautological self-security which repeats the notion of the free-flowing individual, so beloved of the tradition. In dressing this tradition up in the garb of an escape-from-tradition the 2.0 theorist gains a very flexible tool.

31 To match with portfolio identities we have portfolio work which contours identity within the ambit or ecology of the infrastructural move from a previous industrial lifelong workplacedness to a post-industrial 'portfolio working' where work focuses down to a highly mobile individual (the smallest company, as some have coined 'him'). Countless employment studies (for example: Gold. M. 'Managing Self-management: Successful Transitions to Portfolio Careers' in Work, Employment and Society Vol. 16, No 4.) point out this change in the dominant life-time. For a more worked out sociological view see Harvey, D., The Condition of Postmodernity, Blackwell, Oxford, 1989 as well as Smart, B., Modern Conditions, Postmodern Controversies, Routledge, London and New 
York, 1992. Such a transition (and self-reflexive freedom) is however figurally 'triangulated' in the (rather patronisingly self-confident) film 'Billy Elliot', where a boy in a British northern industrial town 'comes out' to his locale as a ballet dancer (and to his somewhat pre-portfolio or 'industrially' situated dad). The key moment in the film comes when the dad recognises his own attitudes are those of a passing age and that he must give way to these new and more mobile identities: his son should be able to choose the mode and identity he likes. Here we have a marked move in the figure of the problematic position of the 'offspring' from 'Saturday Night and Sunday Morning' where Arthur Seaton is punished for his coming-out-of-the-collective through his use of music, drink and adulterous affairs. The traditional pre-reflexive ecology of the time was not yet ripe for choice.

32 Turkle, S., Life on the Screen: Identity in the Age of the Internet, Simon \& Sschuster, New York, 1997.

${ }^{33}$ Filiciak, M., 'Hyperidentities' in The Video Game Theory Reader ed. M.J.P.

Wolf \& B. Perrron (Routledge, 2003) New York and London. pp87-102

${ }^{34}$ Ibid p95-97.

35 ibid. $\mathrm{p} 91$

36 Derrida, J. 'Signature, Event, Context' in 'Margins of Philosophy' (Press, London ) p.149

${ }^{37}$ Bulter ibid. p. 13

${ }^{38}$ As father of Speech-Act theory Austin spoke of acts which could not be judged on any constative truth value but which inaugurate or perform an activity in the very act of saying. This causal-inaugurating of such acts of speech are what Derrida (like his ongoing deconstruction of the speech and writing opposition) problematises back into a citational anteriority, making of the performative a sort of arché-citation much like the famous arché-writing he makes of speech which he then goes on to mobilize as a borrowed and retargeted (against the very conceptual framework borrowed from) tool to work on the tradition.

${ }^{39}$ This is one of Austin's famous performatives with which Derrida takes issue: self-presence as non-iterable (within 'Signature, Event, Context') and in sympathy with which Butler anchors the reading to engage with questions or notions of sex/body (as probmematisers or contourings of 'gender'). Gauntlett ignores this important influence, as some fast and loose freedom with the concept might then have been threatened by such noted conceptual filiations. 
${ }^{40}$ One need only think here of the 'verb' and its connection with the 'verbal'. A 'doing' word can only seem here to 'be done' when it is an originary 'doing'; as is assumed in a performative speech act.

${ }^{41}$ We have to reinforce that the performative that Derrida uses is stretched from the contradictions noted within Austin's theory. Austin's 'performative' haunted by 'constative' (by iteration for example) is Derrida's knowing misuse.

${ }^{42}$ Hence the notion of a 'copyright' that marks off an internal limit from its citational outside (wherein the latter possibility is repressed).

43 Games as such then are not to be seen as strategic campaigns inviting resistant and escalating tactical counter campaigns on the part of the player (a la the counter-tactics cherished by de Certeau and his followers such as Fiske and his playful polysemically-equipped 'semi-active' consumers). Such notions of a firewallable identity are not a part of the game no matter how many boundaries are tried and tested. Here again is a contradiction which both defines the game and reveals why its future, to come, does not lie in any form of recalculated or reconditioned filmic presence. The game involves and always-already accounts for the free-play of the player. The computer can do nothing else than accept such user input. It is not then a war and thus not a real hacking.

${ }^{44}$ Could one talk about a Deleuzean becoming-first or becoming-third or of a fold between? Such a rhizomatic becoming from-the-divide however does not recognise the radicallity of the flickering undecideability between these 'positions' as we hope to elaborate.

${ }_{45}$ Montgomery, R., Lady in the Lake, MGM, 1947.

46 Mulvey, L., 'Visual Pleasure and Narrative Cinema' in Popular Film and Television Tony Bennett (ed), BFI Press, London, pp.206-215.

47 Scott, H.G. \& F. Truffault, Hitchcock. Simon \& Schuster, New York, 1985

48 This small list of three could be expanded and an interesting study undertaken to further problematise the difference between so-called first-person videogames and traditional narrative or diegetic genres that employ the first-person but within the larger narratological web that is the text. This difference needs to be unlocked much more than it is within the literature and the gamic (which should not be reduced either to the ludological, after Caillois and Frasca) quality of the videogame exorcised from these differences.

49 For an examination of the haunted or hauntological nature of the spacetime in videogames see Lockwood, D. \& Richards, T., 'Presence-Play: The Hauntology 
of the Computer Game in 'Games Without Frontiers, War Without Tears: Computer Games as a Sociocultural Phenomenon'. Jahn-Sudmann A., and Stockmann, R., (eds),Palgrave Macmillan, 2008, pp175-185.

50 This perhaps is where the conceptual mistake can occur that games are necessarily like film, because so many games still want to be film (to remediate film). They have perhaps not attuned yet to their gamic potentiality. We would strongly argue then that the game is always already the game no matter how conservatively the nostalgia for film is evidenced, enforced, inscribed or seemingly concretised. There can then, as a product of this view, only be degrees of gamic rather than locatable or ontological differences of 'kind' within the game. A film-game is from bottom a contradiction.

${ }^{51}$ Lionhead Studios., 'Black \& White'

\section{Bibliography}

Aarseth, A,. Cybertext: Perspectives on Ergodic Literature. The Johns Hopkins University Press, Baltimore and London, 1997.

Althusser, L., 'Ideology and Ideological State Apparatuses', in Lenin and Philosophy. New Left Books, London 1972.

Austin, J.L., How to do Things With Words. Harvard University Press, Cambridge, Massachusetts, 1975.

Butler, J., Bodies That Matter. Routledge, New York, 1993.

Butler, J., Gender Trouble. Routledge, New York, 1990.

Caillois, R., Man, Play and Games. University of Illinois Press, Urbana and Chicago, 2001.

Dayan, D., 'The Tutor-Code of Classical Cinema' in Movies and Methods Volume One, Bill Nichols (ed), University of California Press, Berkeley and Los Angeles, 1976, pp.438-450.

de Certeau, M., The Practice of Everyday Life, University of California Press, Berkeley and Los Angeles, 1988. 
Derrida, J., Margins of Philosophy. The University of Chicago Press, Chicago, 1982.

Derrida, J., Limited Inc Northwestern University Press, Evanston, 1988.

Doane, M.A., 'Misrecognition and Identity' in Explorations in Film Theory, ed. Ron Burnett. Indiana University Press, 1991.

Fiske, J.,Television Culture. Routledge, London, 1987.

Gauntlett, D., Media Gender and Identity: An Introduction. Routledge, London, 2002.

Giddens, A. 'Modernity and Self-Identity: Self and Society in the Late Modern Age' Stanford University Press, Stanford, 1991.

Gold, M., 'Managing Self-management: Successful Transitions to Portfolio Careers' in Work, Employment and Society Vol. 16, (No 4.).

Harvey, D., The Condition of Postmodernity, Blackwell, Oxford, 1989.

Heath, S., Questions of Cinema, Macmillan, London, 1981.

Heidegger, M., Being and Time. Blackwell, London 1998.

Lash, S., \& Giddens, A., \& Beck, U., Reflexive Modernisation: Politics, Tradition and Aesthetics in the Modern Social Order, Polity Press, Cambridge and Oxford, 1994.

Lockwood, D. and Richards, T., 'Presence-Play: The Hauntology of the Computer Game' in Computer Games as a Sociocultural Phenomenon: Games Without Frontiers, War Without Tears. Jahn-Sudmann A., and Stockmann, R., (eds), Palgrave Macmillan 2008, pp175-185. 
MacCabe, C. 'Realism and the Cinema: Notes on Some Brechtian Theses' in Popular Television and Film, Tony Bennett (ed), BFI Press, London, pp.216-235.

Metz, C., The Imaginary Signifier: Psychoanalysis and the Cinema, Indiana University Press, Bloomington and Indianapolis, 1986.

Mulvey, L., 'Visual Pleasure and Narrative Cinema' in Popular Television and Film, Tony Bennett (ed), BFI Press, London, pp.206-215.

Osborne, P. \& Segal, L., 'Gender as Performance: An Interview with Judith Butler', Radical Philosophy 67 (Summer 1994), pp32-39.

Rehak, S., 'Playing at Being' in The Video Game Theory Reader ed. M.J.P. Wolf \& B. Perrron, Routledge, New York and London, 2003. p103-127

Rosen, P., Narrative, Apparatus, Ideology, Columbia University Press, New York, 1986.

Scott, H.G. \& F. Truffault, Hitchcock. Simon \& Schuster, New York, 1985

Smart, B. Modern Conditions, Postmodern Controversies. Routledge, London and New York, 1992.

Turkle, S., Life on the Screen: Identity in the Age of the Internet, Simon \& Sschuster, New York, 1997.

Tony Richards is a Senior Lecturer in Media Theory and Production in the Faculty of Media, Humanities and Technology at the University of Lincoln (Lincoln, UK). His main research interests revolve around the relationship of deconstruction to video games as well as the interface of media theory to practice. 